\title{
Intertextuality and autonomous fictional worlds in Disney: the case of Moana (2016)
}

Andrés Pérez-Simón

For Nora and Nadal

In this essay I approach Moana (2016), produced by Walt Disney Animation Studios, with a special focus on a musical scene that represents the counterargument of what is ostensibly the main lesson in the film (the "look-inside-yourself" motif so central to many Disney titles). I am referring to the scene in which the young heroine Moana, daughter of the chief of a Polynesian island, faces the giant crab Tamatoa in the undersea environment of Lalotai, also known as "The Realm of Monsters." At the request of Moana, who tries to distract him by feeding his ego, Tamatoa agrees to introduce himself "in song form" (this is, of course, a self-referential statement that lays bare the conventions of musical films) and then proceeds to perform the song "Shiny," the main object of my analysis here. This song was composed by Lin-Manuel Miranda (creator of the Broadway musicals In the Heights and Hamilton) and Mark Mancina, with lyrics by Miranda; it is performed by actor and musician Jemaine Clement, member of the comedy duo Flight of the Conchords. The "Shiny" scene contains very explicit intertextual references to the figure of David Bowie, an aspect that makes this scene exceptional in contrast to Disney's common practice of creating fictional worlds that appear to us as self-sufficient entities somehow insulated from external references, as I will comment on later.

My essay renders homage to Petr Bogatyrev's 1938 essay on Snow White, the first structuralist essay on what was Disney's first full-length animated movie ever. As it is well known, Petr Bogatyrev wrote "Chaplin and The Kid" and "Chaplin, the Fake Count" in 1923, two articles studying the construction patterns in three of Charles Chaplin's films - The Kid, The Count and The Immigrant. In studying Chaplin's art Bogatyrev paid special attention to elements of plot construction such as contrast, retardation and so on, operating within the theoretical framework established by Viktor Shklovsky (ostranenie, "how art is made", etc.), who was the editor of the collection of essays on Chaplin. Fifteen years later, in 1938, Bogatyrev published 
"Disney's Snow White" as his immediate response to Snow White and the Seven Dwarfs, Disney's first full-length animated film. It premiered in Los Angeles in late December of 1937 and released in the rest of the US, Canada and Europe in 1938. The theoretical landscape had significantly changed in the time between Bogatyrev's two early essays on Chaplin and his new take on Disney's Snow White, the latter now informed by Otakar Zich's concept of "stage figure," conceptualized in his Aesthetics of Dramatic Art (1931) as well as Jan Mukařovský's structural approach to film in the early 1930s (Mukařovský's first essay on film is precisely an article on Chaplin's own City Lights, published in 1931). On the idea of stage figure, I will note that one aspect of Disney's Snow White that attracts Bogatyrev's attention is how the drawing techniques in this film render animals and human characters with "drawn details [...] but only those that are necessary for [their] movement and for [their] characterization" (BOGATYREV 2008: 278). This is in accordance with a principle that "presupposes the perfect functionality of each single trait for each figure and guarantees that the filmic expression will not be weakened by anything that lacks use or function" (BOGATYREV 2008: 278). This preeminence of functionality contrasts with a typical problem of theater acting, one that Bogatyrev described in an essay from 1937, one year before writing on Snow White, in terms of the actor's work being "firmly restrained by the acting of his partners" (BOGATYREV 2016c [1937]: 168).

A second aspect of Bogatyrev's piece on Snow White, and one that is a direct inspiration of my essay, concerns the presence of irony in doubly coded artifacts that address the tastes and expectations of two different age groups simultaneously. Building on a tradition of thought that began with Shklovsky and continued with Jurij Tynianov, in particular his view on parody as a method of evolution of the historical series, Bogatyrev writes that in order to "re-invigorate the old creative means, the artist resorts to an ironic mode. If he succeeds in bringing a gentle irony to the old, "worn out' technique, he creates an impression that is half serious and half ironic" (BOGATYREV 2008: 279). This co-presence of two artistic languages, spotted by Bogatyrev, has constituted a feature mark of Disney's films until today. Moreover, the influence of Mukařovskýs phenomenological aesthetics can be found in Bogatyrev's assertion that "for some viewers [of Snow White], the dominant element is the ironic one, while for others it is the serious one" (BOGATYREV 2008: 279). We could go beyond and interpret Bogatyrev's essay as a precedent for Felix Vodička's reception theories of the 1940s, particularly when considering that Bogatyrev suggests as methodology for further research the polling of children and adults after exiting the cinema in order to compare their different reactions to Snow White.

It is in this spirit of discovery that characterized Bogatyrev's essay on Snow White that I propose a brief reflection on Moana in this present essay. In recent decades there has been a relatively low number of articles on film by practitioners of Prague School structural analysis, both inside and outside the confines of the Czech Republic (see SLÁDEK 2015 for a history of émigré scholars in the USA), and to my knowledge none of these essays has dealt with the Walt Disney Pictures. My aim is to open a line of dialogue with contemporary scholars not identified with the Prague School tradition. 
Directors John Musker and Ron Clements conceived Moana inspired by the real story of a tribe of native peoples of the Pacific that, after mastering long-distance sailing for centuries, suddenly stopped making long-distance voyages for reasons unknown to historians (it is speculated that it was due to changes in ocean currents and wind patterns). This occurred three thousand years ago, and it is estimated that it took them one thousand years to resume their travels. This temporal hiatus provides the background for the conflict that exists in the film between by the desires of an individual and the interests of her group as a whole. On the one hand there is Moana, the daughter of the tribe's chief who is disinterested in continuing her family's reign over the island. She insists on learning how to sail, with the only support of her grandmother, who eventually reveals to her the glorious past of their tribe ("we were voyagers!," Moana exclaims in the epiphanic moment of discovery). On the other hand emerges Moana's father, who has strictly enforced the prohibition of sailing beyond the reef despite the fact that, after centuries of isolation, the tribe now finds itself trapped in what basically constitutes a barren island. My main interest is in those aspects of Moana that establish a rupture from the cinematic conventions upheld by Walt Disney Pictures since the release of Snow White in 1937. These novel traits become explicit in the scene in which the young heroine Moana, daughter of the chief of a Polynesian island, faces the giant crab Tamatoa in the undersea environment of Lalotai. In good old epic fashion, Moana uses her cunning to deceive Tamatoa into believing that she is interested in hearing the story of his life. In reality, her petition is a simple strategy to buy time while her partner Maui finds a way to recover a magical hook that Tamatoa has in his possession.

\section{The autonomous world of Disney}

Since the production of Snow White up until the present the Walt Disney Pictures has conceptualized full-length movies as illusionist artifacts essentially sealed off from their outside. Two central strategies in the creation of self-contained fictional worlds are: in the first place, the commission of original, epic soundtracks that make the films impermeable to pop culture (Universal Pictures' Despicable Me 3, released in 2017, does quite the opposite, celebrating pop culture by featuring song by Michael Jackson, Madonna, and A-Ha); secondly, the systematic absence of intertextual references to cultural productions other than those by Disney itself (the so-called "Easter Eggs," I will touch on this aspect later). It is with these two premises in mind that we can better understand the exceptional nature of the "Shiny" scene in Moana, for it is a scene that deviates from these two compositional principles.

As Matthew W. Smith observes, Walt Disney's original vision of progress was one "linked to a longing for European antiquity" (SMITH 2007: 119) mostly identified with the folkloric materials compiled by the Brothers Grimm and Charles Perrault - hence his remakes of Little Red Riding Hood, The Four Musicians of Bremen, Puss in Boots as silent cartoons in the beginnings of his career in the early 1920s. Once consolidated as an industry leader in Hollywood in the 1930s - his Silly Symphonies series, 75 animated 
short films in the latest Technicolor version, ran from 1929 to 1939 - and in the wake of the worldwide success of Snow White Walt Disney continued creating works of escapist fiction. Up to today, indeed, the Walt Disney Pictures have systematically resisted the intrusion of contemporary, exterior reality, in their films, an isolationist stance that has not neutralized several controversies fueled by interpretations pointing at the existence of a racist bias in Disney films. ${ }^{1}$ This positioning towards the world out there has been attacked by critics such as Henry Giroux, who claims that the Walt Disney Company "is not ignorant of history" but rather "reinvents it as a pedagogical and political tool to secure its own interests, authority, and power" (GIROUX 1995: 27). Giroux argues that Disney's "strategies of entertaining escapism, historical forgetting, and repressive pedagogy [...] produce a series of identifications that relentlessly define America as white and middle class. Pedagogy in Disney's texts functions as a history lesson that excludes the subversive elements of memory" (GIROUX 2007: 27).

Unlike Giroux's, however, the main goal of the present essay is not what can be defined, in plain terms, as the ideology of Disney's films, but rather the conceptualization of Disney's art in ontological terms, as an autonomous and self-standing world. Lubomír Doležel argues that the question of referential truth was never addressed by the Prague School structuralists. In his view, the Prague scholars "did not proclaim poetic language self-referential but left the concept of poetic reference underdeveloped" (DOLEŽEL 1990: 229, n. 9). Doležel observes that Mukařovský "accepted the concept of poetic reference but relegated it to the margin of poetics" (DOLEŽEL 1990: 165). The problem, according to Doležel, is that the influence of "Saussurean nonreferential semantics" prevented Prague scholars "from appreciating the importance of the reference relation which links literature to the world" (DOLEŽEL 1990: 167). More recently, Ondřej Sládek, while partially agreeing with Doležel in that "the Prague School did not work with the idea that a literary work represented a specific reality, a special "model of the world'" (SLÁDEK 2006: 210-211), has argued that an early version of the idea of "fictional world" can be found in the works of Mukařovsky and Vodička. In his analysis of Vodička's concept of "context of the external world," Sládek explains that it "comprises both social relations and psychological descriptions on the one hand and the historical, spiritual, and ideological atmosphere in which the characters live and where the story takes place on the other" (SLÁDEK 2006: 212). The caveat is, Sládek notes, that in Vodička's formulation this concept appears linked to the other two thematic levels that form the work - the story and the characters - which means that its autonomy is limited (SLÁDEK 2006: 212). In Vodička's formulation, therefore, there is a "literary reality" and it is not connected to what we might refer to as the empirical reality.

Doležel, differently to Vodička, insists on the need to acknowledge two types of texts, those that represent the actual world and those that create a fictional possible world (DOLEŽEL 1998: 24), as a first step towards studying the potential between them. He argues that fictional worlds "contain 'fictional particulars' which have the ontological

1 For racial identifications in The Jungle Book see (MILLER and RODE 1995: 45), on the "Jim Crows" characters in Dumbo and the hypersexualized five African-American muses in Hercules see (FOOTE 2011: 15), on the controversy around Tiana, the first African-American princess, see (FOOTE 2011: 15-16). 
status of "nonactualized possibles"” (DOLEŽEL 1998: 16). This means that fictional characters, also nonactualized possibles, cannot meet real people and are not subject to truth validation. Doležel does recognize the possibility of this happening in genres such as the historical novel, and what occurs in this case is that these interactions are ruled by a "transworld identity" that is generally regulated by verisimilitude (DOLEŽEL 1998: 17). This idea of "transworld identity" inspires my reflection on intertextuality and Disney films, but at the same time I consider it is necessary to go beyond Doležel's take on intertextuality. Doležel identifies to intertextuality as the frequent postmodern practice of producing prequels and sequels to source worlds (DOLEŽEL 2010: 217). My focus is not on the connection texts of the same nature, but rather to explore a different phenomenon, say, when a giant crustacean identifiable with David Bowie bursts into a scene in a Disney film.

While Dreamworks and Universal Studios heavily rely on the comic effects of intertextuality with popular culture artifacts, as any spectator of the Shrek trilogy (on double coding in Shrek, see ZEENAT 2017) or the Despicable Me series can notice, in recent years Disney has rather preferred to accentuate its ontological self-sufficiency by instructing its fans in the pursuit of "Easter eggs". The term Easter egg became known in the entertainment industry in 1979, when one of the software programmers of Atari encoded his signature in a videogame of his creation, much like the hidden signature of the author of a medieval painting. The insertion of secret messages and special rewards was a relatively common practice in the videogame world in the 1980s, and the Easter eggs functioned as coveted prizes that would provide the players' avatars with special powers, extra lives, and so on. In the home cinema industry at large, the concept of Easter egg became synonym of 'extra features' with the commercialization of DVDs in the late 1990s. What Disney does, however, is not a question of simply including deleted scenes or bonus features in their DVDs (Disney does that too, of course) but, rather differently, its Easter eggs operate as very specific intertextual references to characters in other Disney movies. They materialize mostly in the form of Disney characters cameos (a short haired, brunette Rapunzel attending Princess Elsa's coronation in Frozen, for example), or objects that stand for characters (the spinning wheel of Sleeping Beauty in the background of one scene in Tangled). To put it succinctly, intertextuality in Disney films reinforces a previously existent Disney world and has no aim to refer watchers to symbols of motifs from a non-Disney space. The legal correlate of Disney's narrow conception of intertextuality is, predictably, its exclusionary stance towards copyright. This is a topic that falls outside the scope of this essay, so I will only mention here Disney's capital influence in the Copyright Act of 1976, which extended copyright protection from 56 to 75 years; and the Copyright Term Extension Act of 1998, popularly known as the Mickey Mouse Protection Act, which extended copyright for another 20 years, making it a total of 95 years. Mickey Mouse's first appearance was in 1928, in the short film Steamboat Willie, which means his last year with copyright will be 2023 .

The volume The Quotable Walt Disney (2001) contains a number of quotations documenting Walt Disney's obsession with the Disneyland theme park as a separate entity: "To step through the portals of Disneyland will be like entering another world" 
(SMITH 2001: 47); "Physically, Disneyland would be a small world in itself" (SMITH 2001: 48); "I don't want the public to see the world they live in while they're in [Disneyland]. I want them to feel they're in another world" (SMITH 2001: 59), and so on. The insulated nature of Disney's fictional worlds is manifest nowhere better than in Walt Disney's ultimate fantasy realization, the theme parks Disneyland (opened in 1955 in Anaheim, California) and Walt Disney World (founded in 1971, near Orlando, Florida). ${ }^{2}$ On this issue, Matthew Smith has established a parallelism between Walt Disney's theme parks and Richard Wagner's Bayreuth festival in view of their common efforts to produce a grand to re-harmonize humanity and nature through the notion of 'total performance.' "Disney's work, like Wagner's," observes Smith, "was launched against the degraded condition of modern 'culture', against the dark side of industrial capitalism. More importantly, Disney's project, particularly in the theme parks, was to create a grand unification of all the arts" (SMITH 2007: 116). After purchasing about 200 acres of land, Disney bulldozed it and created "a stage upon which to manufacture an entirely new landscape of hills, valleys, and lakes" (SMITH 2007: 122), an artificial environment that was supposed not to be affected by external agents (Disney negotiated with the Town Council to prevent tall buildings from being erected in the vicinities, and he paid telephone companies to bury telephone poles around his park). ${ }^{3}$ By the mid-1960s, however, Disneyland had been surrounded by restaurants and hotels that had flourished around a park that was relatively small. Walt Disney understood that to exercise total control over his fantasy world he should work on a larger scale. He purchased 27,000 acres in Florida, and after intensive negotiations and lobbying with the Florida legislature, the new theme park obtained the status of district with the powers of an incorporated city. Since 1971, the Walt Disney World complex has operated, in Smith's words, as a "virtually independent state" (SMITH 2007: 129). ${ }^{4}$

Illusionism reigns in the Disney parks. Smith has noted the particular function of the so-called "utilidors", a network of underground tunnels that in addition to housing storage facilities, staff cafeterias and dressing rooms;

also provide a means for characters to leave one mythic zone without passing through another. Thus a space-suited actor from Tomorrow-land can make his way to the parking lot while still in costume without having to cross through the cowboy country of Frontierland. In this way the utilidors serve not only as a means of sweeping away the refuse of the "outside" world. (SMITH 2007: 130-131)

2 There is a total of twelve Disney parks in six Disney resorts around the world (Japan, France, Hong Kong and China, following after the resorts in California and Florida). Within the confines of the Tokyo Disney Resort, the park Tokyo DisneySea, opened in 2001, is tailored for an aging population, thus complementing the more traditional, children-oriented thematic park that is Tokyo Disneyland.

3 See (SMITH 2007: 122) for more details.

4 This is not unique to the Florida theme park; for further reading on Disney's strategies of tax "escapism" in California, see Daniel Miller's article “Is Disney paying its share in Anaheim?” published in the Los Angeles Times September $24^{\text {th }}$, 2017. 


\section{The curious case of David Bowie}

As noted earlier, while parody and pastiche play a central role in the films of Dreamworks and Universal Studios, the inclusion of pop culture has rarely been an integral part of Disney animated films, with the exception of Robin Williams' virtuous impressions in his role of Genie in Aladdin (1992). In Moana, the song "Shiny" offers multiples clues that direct the spectators' attention to the very recognizable figure of David Bowie. In this song, Miranda embeds multiple intertextual references to Bowie's music (he wrote it in early 2016, as a tribute to Bowie, who had passed away a few weeks earlier) while singer Jemaine Clement, famous for different impersonations of Bowie, accentuates the similarities with Bowie's style by adopting his "copyrighted" voice mannerisms. The question to be asked is why David Bowie is the perfect figure to invoke in order to rupture the illusion. The answer, I submit, is to be found in Bowie's overtly theatricalist idea of musical performance. In his teen years Bowie received training in dance, and mime and movement (he studied under Lindsay Kemp in the late 1960s), and it was this background that separated him from other contemporary rock stars. As Philip Auslander notes, Bowie "not only envisioned the rock concert as a staged, costumed, and choreographed theatrical performance, he understood his own performing and his relationship to his audience in actorly terms rather than the communitarian terms that defined performance for psychedelic rockers" (AUSLANDER 2006: 106). It was through his "actorly" style that Bowie was able to produce different personas through the years, and it was through this style that the succeeded in exposing the connection between performativity and theatricality on the musical stage. In an interview from 1971, for example, he explained his upcoming plans to "play a character called Ziggy Stardust. We're going to do it as a stage show. We may even do it in the West End. When I'm tired of playing Ziggy I can step out and someone else can take over for me." One year later, in an interview with Rolling Stone magazine, he declared: "I feel like an actor when I'm on stage, rather than a rock artist" (qtd. AUSLANDER 2006: 109). Auslander notes the importance of musical theater for Bowie, at a time, the late sixties and early seventies, when rock artists were expected to create a stable persona to be interpreted as "authentic" expressions of their selves. In Auslander's words, this idea of "rock authenticity is linked with the romantic bent of rock culture, in which rock music is imagined to be truly expressive of the artists' souls and psyches, and is necessarily politically and culturally oppositional" (AUSLANDER 2008: 81). Contrary to this tendency, Bowie adopted many masks and avoided presenting a consistent persona by doing different voices and accents as if imitating dramatic characters even since his first album, from 1967 (the songs "Rubber Band" and "Please Mr. Gravedigger" are two transparent examples of Bowie's first "actorly" incursion in music). Glam rock challenged established notions of gender identity "not only because glam offered a new, implicitly queer, image of masculinity in rock but also because it disputed the ideology of authenticity by positing gendered identities as constructed rather than natural" (AUSLANDER 2006: 40). Bowie's theatricalist figure, in sum, provided Miranda with the perfect cultural referent to invoke in conveying a message of celebration of the 
playful game of external differences, precisely the counterargument to Moana's overall theme of the quest of authenticity.

\section{"Shiny," or when the outside is what really matters}

The exceptional nature of the "Shiny" scene in Moana becomes evident when interpreted in contrast to the overwhelmingly illusionist aesthetics of the Walt Disney Pictures as well as in opposition to Disney titles that have pivoted around the motif of the quest for authenticity. In Beauty and the Beast (1991), the vindication of the "beautiful" inside, in contrast to external appearances, reaches new heights when Belle falls in love with the Beast's good heart - what follows afterwards is the convenient physical transformation of Beast into a handsome prince, of course; in Aladdin (1992), the use of royal disguises, for example, does the trick for a certain time, but it is only when Aladdin opens up and confesses he is not really a prince that the sultan's daughter agrees to marry him; in Mulan (1998), the title character removes the makeup she identifies with a false life and sings "Reflection" ("I will never pass for a perfect bride, or a perfect daughter [...] Who is that girl I see, staring straight back at me / Why is my reflection some I don't know"). I see all these cases as variations of what William Egginton defines as an intrinsically modern problem of thought, traceable back to the historical period we know as Baroque, a problem that "concerns the relation of appearances to the world they ostensibly represent" (EGGINTON 2009: 144). What Egginton defines as the "major strategy of the baroque" is one that keeps returning in Disney movies in the form of a discourse that promises a glimpse of truth behind the veil of appearances. This is in correspondence with "Hollywood's institutionalized major strategy of guiding the viewer toward some true insight on the other side of all that representation" (EGGINTON 2010: 121). There is, however, a marginal and relatively unexplored strategy in the history of Western art, a "minor strategy" that shows us, from the very beginning, that "the supposed purity behind the wall of appearances is already corrupted by the distinction that created it" (EGGINTON 2009: 145). Moana constitutes a peculiar case in the trajectory of the Walt Disney Studios in the sense that it is a film that fully embraces the "listen-toyour-heart" rhetoric of authenticity (Moana's grandmother teaches her to always trusts her instincts; Moana leaves the island, challenges the dangers of nature and eventually restores the balance of nature by restoring the heart, of all the body organs, of the goddess Tafiti), but at the same time this film contains the counterargument to this whole discursive logic. The deconstruction of this main idea takes place in the scene in which Moana and her fellow traveler, Maui, navigate the underworld of Tamatoa. The giant crab puts it very efficiently in the opening lines of his autobiographical song "Shiny":

Did your granny say "listen to your heart",

"Be who you are on the inside",

I need three words to tear her argument apart:

Your granny lied! 
Tamatoa privileges theatricality, and the potentially infinite of chain of signs it mobilizes, over the idea of transcendental truthfulness lying behind external appearances. He identifies himself as "Shiny," the crustacean who has made a way of life out of dandyism by incorporating into his body any sparkly objet that has fallen into the bottom of the ocean. He has become a living work of art ("I made myself a work of art / I'll never hide; I can't, I'm too / Shiny") that uses his highly aestheticized body with very practical purposes, namely feeding on fish that are attracted to his brightness ("Fish are dumb, dumb, dumb / They chase anything that glitters"). It is worth noting that, in discussing "Shiny" in an interview on occasion of the commercial release of Moana in 2016, composer Lin-Manuel Miranda referred to this song as "the anti-lesson of the movie" in view of the contrast between Moana and Tamatoa. If Moana, Miranda explains, embarks on a journey to find out "what that voice inside her says and who she is," the priority for Tamatoa is precisely what remains on the outside. In Miranda's words, "It's about how you look!" He [Tamatoa] is from the deepest, darkest part of the sea. Your armor is important, the glitter that attracts prey is important".

Egginton, who defines the Baroque as "the cultural aspect of representationalism" (EGGINTON 2010: 107), sees the "minor strategy" as "a way of thinking that valorizes appearances for themselves instead of as stand-ins for some ever-receding truth" (EGGINTON 2010: 108). Among contemporary cultural productions, Egginton sees the cinema of Pedro Almódovar as a perfect example of what constitutes "an aesthetics oriented according to the Baroque's minor strategy", one that puts into question "the fundamental presupposition of the metaphysics of everyday life [...] that the self in its truth is naked, pure, unadorned" (EGGINTON 2010: 108). My argument in this essay has been that Disney's film Moana also represents an example, albeit necessarily partial, of a minor strategy brilliantly put at work by musician Lin-Manuel Miranda in close dialogue with the film's screenwriters. In performing "Shiny" before Moana, the young heroine in search of an inner truth that will eventually restore the balance between her community and the natural world, the giant crab Tamatoa defends a notion of authenticity that brings us back to baroque conceptualizations of the persona, the mask, as "an artificial site of theatrical performance and social negotiations" (CASTILLO and EGGINTON 2016: 4). Tamatoa's discourse pierces through the dominant discourse of authenticity in the film, and even though after Moana's adventure in the marine underworld - the epic plot resumes its linear progression towards the final revelation expected in a Disney film - I find it significant that at the end of the story, the giant crab remains the only one unaffected by Moana's actions. The film ends with a spectacular sequence of Moana's people sailing the Pacific again, a community of voyagers lead by the intelligent and brave young woman who will soon become their leader, yet after the closing credits have rolled we can see a short post-credit scene that features Tamatoa lying upside-down, still in the same position he was left when Moana and his partner Maui fled the so-called Realm of Monsters. Exhausted and unable to move, he sings: "... Shiny... I'm so shiny...". 
In this essay I have discussed the existence of two parallel aesthetic discourses in Moana, each of them with evident ideological implications as they directly relate to the issue of representationalism. What Egginton defines as the "major" strategy is still dominant in the film, and Moana, the epic heroine, eventually reaches the final truth by defeating appearances. My claim is that, by presenting the giant crab Tamatoa as a character embodying the "minor" strategy, the creators of Moana are opening up a path not explored before by Walt Disney Animation Studios. One last aspect to consider is that the dichotomy form/content cannot account for this partial innovation. This new phenomenon concurrently manifests in different layers of the film, with intertextuality and parody operating as the two main elements that blur the distinctions between form and meaning and that, ultimately, make possible an ontological construction alternative to the self-referential fictional worlds that are typical of the Walt Disney films.

\section{Bibliography}

AUSLANDER, Philip. 2006. Performing glam rock: gender and theatricality in popular music. Ann Arbor: University of Michigan Press, 2006.

AUSLANDER, Philip. 2008. Liveness: performance in a mediatized culture. $2^{\text {nd }}$ ed. New York: Routledge, 2008.

BELL, Elizabeth, Haas LYNDA and Laura SELLS (eds.). 1995. From mouse to mermaid: the politics of film, gender and culture. Bloomington: Indiana UP, 1995.

BOGATYREV, Petr. 2008. Disney's Snow White. In Jaroslav Andel and Petr Szcepanik (eds.) (trans. Kevin B. Johnson). Cinema all the time: an anthology of Czech film theory and criticism, 1908-1909. Ann Arbor: University of Michigan Press, 2008: 277-280.

BOGATYREV, Petr. 2016a [1923]. Chaplin and The Kid. In David Drozd, Tomáš Kačer and Don Sparling (eds.). 2016. Theatre theory reader: Prague School writings. Prague: Karolinum Press, 2016: $175-184$.

BOGATYREV, Petr. 2016b [1923]. Chaplin, the Fake Count. In David Drozd, Tomáš Kačer and Don Sparling (eds.). 2016. Theatre theory reader: Prague School writings. Prague: Karolinum Press, 2016: 185-191.

BOGATYREV, Petr. 2016c [1937]. Playing and the Theatre. In David Drozd, Tomáš Kačer and Don Sparling (eds.). 2016. Theatre theory reader: Prague School writings. Prague: Karolinum Press, 2016: 168-174.

CASTILLO, David R. and William EGGINTON. 2016. Medialogies: reading reality in the age of inflationary media. New York: Continuum, 2016.

DOLEŽEL, Lubomír. 1990. Occidental poetics: tradition and progress. Lincoln/London: University of Nebraska Press, 1990.

DOLEŽEL, Lubomír. 1998. Heterocosmica: fiction and possible worlds. Baltimore/London: The Johns Hopkins UP, 1998.

DOLEŽEL, Lubomír. 2010. Possible worlds of fiction and history: the postmodern stage. Baltimore: The Johns Hopkins UP, 2010.

DROZD, David, Tomáš KAČER and Don SPARLING (eds.). 2016. Theatre theory reader: Prague School writings. Prague: Karolinum Press, 2016. 
EGGINTON, William. 2009. The Baroque as a Problem of Thought. PMLA 124 (2009): 1: 143149.

EGGINTON, William. 2010. The theater of truth: the ideology of (Neo)Baroque aesthetics. Stanford: Stanford UP, 2010.

FOOTE, Lena. 2011. "I want to be a princess too": exploring the blackout of Disney's princesses and vontroversies surrounding The Princess and the Frog and its effects on African American girls. Film Matters 2 (2011): 3: 13-22.

GIROUX, Henry A. 1995. Memory and pedagogy in the "Wonderful World of Disney": beyond the politics of innocence. In Elizabeth Bell, Haas Lynda and Laura Sells (eds.). From mouse to mermaid: the politics of film, gender and culture. Bloomington: Indiana UP, 1995: 26-32.

MILLER, Daniel. 2017. "Is Disney paying its share in Anaheim?”. Los Angeles Times (24. 9. 2017).

MILLER, Susan and Greg RODE. 1995. The movie you see, the movie you don't: how Disney do's that old time derision. In Elizabeth Bell, Haas Lynda and Laura Sells (eds.). From mouse to mermaid: the politics of film, gender and culture. Bloomington: Indiana UP, 1995: 86-104.

MUKAŘOVSKÝ, Jan. 2016. An attempt at a structural analysis of an actor's figure (Chaplin in City Lights). In David Drozd, Tomáš Kačer and Don Sparling (eds.). 2016. Theatre theory reader: Prague School writings. Prague: Karolinum Press, 2016: 192-98.

SLÁDEK, Ondřej. 2006. Types of worlds: on relations between the Prague School and the theory of fictional worlds. Style 40 (2006): 3: 210-20.

SLÁDEK, Ondřej. 2015. The metamorphoses of Prague School structural poetics. Munich: LINCOM, 2015.

SMITH, Dave. 2001. The quotable Walt Disney. New York: Disney Editions, 2001.

SMITH, Matthew W. 2007. The total work of art: from Bayreuth to cyberspace. London: Routledge, 2007.

ZEENAT, Afrin. 2017. "You are all wrapped up in layers": pastiche, paradox, and Shrek. Studies in American Culture 40 (2017): 1: 109-123.

ZIPES, Jack. 1995. Breaking the Disney spell. In Elizabeth Bell, Haas Lynda and Laura Sells (eds.). From mouse to mermaid: the politics of film, gender and culture. Bloomington: Indiana UP, 1995: 16-25. 